\title{
Crystal structure, quantum mechanical investigation, IR and NMR spectroscopy of two new organic salts: $\left(\mathrm{C}_{8} \mathrm{H}_{12} \mathrm{NO}\right) \cdot\left[\mathrm{NO}_{3}\right](\mathrm{I})$ and $\left(\mathrm{C}_{8} \mathrm{H}_{14} \mathrm{~N}_{4}\right) \cdot\left[\mathrm{ClO}_{4}\right]_{2}(\mathrm{II})$
}

\author{
I. Bayar a , L. Khedhiri a , S. Soudani a , F. Lefebvre ${ }^{\text {b }}$, P.S. Pereira da Silva ${ }^{\text {c }}$, C. Ben Nasr ${ }^{\text {a, * }}$ \\ a Laboratoire de Chimie des Matériaux, Faculté des Sciences de Bizerte, 7021, Zarzouna, Université de Carthage, Tunisie \\ ${ }^{\mathrm{b}}$ Laboratoire de Chimie Organométallique de Surface (LCOMS), Ecole Supérieure de Chimie Physique Electronique, 69626, Villeurbanne Cedex, France

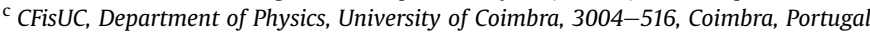

\section{A R T I C L E I N F O}

\section{Article history:}

Received 2 January 2018

Received in revised form

7 February 2018

Accepted 8 February 2018

Available online 9 February 2018

\section{Keywords:}

Single crystal X-ray diffraction analysis

Solid-state NMR

Hirshfeld surface

DFT calculations

\begin{abstract}
A B S T R A C T
Two new organic-inorganic hybrid materials, 4-methoxybenzylammonium nitrate, $\left(\mathrm{C}_{8} \mathrm{H}_{12} \mathrm{NO}\right) \cdot\left[\mathrm{NO}_{3}\right](\mathbf{I})$, and 2-(1-piperazinyl)pyrimidinium bis(perchlorate), $\left(\mathrm{C}_{8} \mathrm{H}_{14} \mathrm{~N}_{4}\right) \cdot\left[\mathrm{ClO}_{4}\right]_{2}$ (II), have been synthesized by an acid/base reaction at room temperature, their structures were determined by single crystal X-ray diffraction. Compound (I) crystallizes in the orthorhombic system and Pnma space group with $a=15.7908$ (7), $b=6.8032$ (3), $c=8.7091$ (4) $\AA, V=935.60$ (7) $\AA^{3}$ with $Z=4$. Full-matrix least-squares refinement converged at $R=0.038$ and $\mathrm{w} R\left(F^{2}\right)=0.115$. Compound (II) belongs to the monoclinic system, space group $P 2_{1} / c$ with the following parameters: $a=10.798(2), b=7.330(1), c=21.186(2) \AA$, $\beta=120.641$ $(4)^{\circ}, V=1442.7$ (3) $\AA^{3}$ and $Z=4$. The structure was refined to $R=0.044, w R\left(F^{2}\right)=0.132$.

In the structures of $(\mathbf{I})$ and $(\mathbf{I I})$, the anionic and cationic entities are interconnected by hydrogen bonding contacts forming three-dimensional networks. Intermolecular interactions were investigated by Hirshfeld surfaces and the contacts of the four different chloride atoms in (II) were compared. The Molecular Electrostatic Potential (MEP) maps and the HOMO and LUMO energy gaps of both compounds were computed. The vibrational absorption bands were identified by infrared spectroscopy. These compounds were also investigated by solid-state ${ }^{13} \mathrm{C},{ }^{35} \mathrm{Cl}$ and ${ }^{15} \mathrm{~N}$ NMR spectroscopy. DFT calculations allowed the attribution of the IR and NMR bands.
\end{abstract}

() 2018 Elsevier B.V. All rights reserved.

\section{Introduction}

Hydrogen bonds of hybrid compounds are of great interest because of their widespread biological occurrence [1,2]. The supramolecular networks become especially interesting when the cation and anion can participate in hydrogen-bonding. In recent years, much attention has been devoted to the study of perchlorate and nitrate salts containing organic cations owing to their interesting properties such as ferroelectric and dielectric behaviors [3-5].

Perchlorate and nitrate anions are Lewis bases used as ligands for the elaboration of metal complexes having interesting applications in various fields: stabilization of PVC, protection of wood, catalysis, pesticides, fungicides, pharmacology, etc. [6-10]. Several organic cations (such as protonated amines) can be used for the stabilization of these anions especially benzylammonium and pyrimidinium derivatives [11,12].

Benzylamine and its derivatives have been widely studied as precursors in organic synthesis. They are also used in the industrial production of many pharmaceuticals including alniditan, lacosamide, moxifloxacin, and nebivolol [13-17].

Pyrimidine and its derivatives are biologically important as they occur in nature as components of nucleic acid. Some pyrimidine derivatives are used as antifolate drugs [18].

In order to enhance the varieties of materials and to examine the influence of hydrogen bonds on the chemical and structural features, we report herein the chemical preparation and crystal structure of two new organic salts, $\left(\mathrm{C}_{8} \mathrm{H}_{12} \mathrm{NO}\right) \cdot\left[\mathrm{NO}_{3}\right]$ (I) and $\left(\mathrm{C}_{8} \mathrm{H}_{14} \mathrm{~N}_{4}\right) \cdot\left[\mathrm{ClO}_{4}\right]_{2}(\mathrm{II})$.

\footnotetext{
* Corresponding author.

E-mail address: cherif_bennasr@yahoo.fr (C. Ben Nasr).
} 


\section{Experimental}

\subsection{Chemical preparation}

$\left(\mathrm{C}_{8} \mathrm{H}_{12} \mathrm{NO}\right) \cdot\left[\mathrm{NO}_{3}\right](\mathrm{I})$ and $\left(\mathrm{C}_{8} \mathrm{H}_{14} \mathrm{~N}_{4}\right) \cdot\left[\mathrm{ClO}_{4}\right]_{2}$ (II) were obtained by slow evaporation at room temperature of aqueous solutions of 4methoxybenzylamine (I) or 2-(1-piperazinyl)pyrimidine (II) with the corresponding concentrated acid (cold $65 \% \mathrm{HNO}_{3}$ and cold $70 \%$ $\mathrm{HClO}_{4}$ ) in the stoichiometric ratio $1: 1$ (I) and 1:2 (II). The solutions were stirred for $15 \mathrm{~min}$ and allowed to stand at room temperature. Single crystals having the form of sticks appeared after a few days and could be subjected to X-ray diffraction analysis. The products were then filtered off and washed with a small amount of distilled water.

\subsection{Investigation techniques}

\subsubsection{X-ray single crystal structural analysis}

Suitable crystals of (I) and (II) were selected and mounted on a Bruker APEX2 CCD area-detector diffractometer, using MoK $\alpha$ radiation $(\lambda=0.71073 \AA)$. The intensities were collected at $293 \mathrm{~K}$, integrated using the Denzo-SMN package [19] and corrected for Lorentz-polarization and absorption effects [20]. Both structures were solved by direct methods with SIR97 [21] and the least-square refinement on $\mathrm{F}^{2}$ was achieved using SHELXL-97 [22] implemented in the WINGX system of programs [23] with all non-hydrogen atoms anisotropic. All the hydrogen atoms were situated in geometrically optimized positions and treated as riding atoms, apart from those bound to $\mathrm{N} / \mathrm{O}$ atoms in (I) which were found in the difference Fourier map and refined isotropically with restrained distances. The drawings were made with Diamond [24]. Experimental details, crystallographic and processing data are reported in Table 1.

Crystallographic data for the structural analysis have been deposited at the Cambridge Crystallographic Data Centre, CCDC No 1551531 for (I) and CCDC No 1551533 for (II). These data can be obtained free of charge via http://www.ccdc.cam.ac.uk/conts/ retrieving.html, or from the CCDC, 12 Union Road, Cambridge, CB2 1EZ, UK: fax: (+44) 01223-336-033; e-mail: deposit@ccdc.cam. ac.

\subsubsection{NMR and IR measurements}

The ${ }^{13} \mathrm{C}$ NMR spectra were recorded on a solid-state high-resolution Bruker Avance-300 spectrometer operating at $75.47 \mathrm{MHz}$ The ${ }^{15} \mathrm{~N}$ and ${ }^{35} \mathrm{Cl}$ NMR spectra were recorded on a Bruker Avance500 spectrometer operating at $50.67 \mathrm{MHz}$ for ${ }^{15} \mathrm{~N}$ and $49.00 \mathrm{MHz}$ for ${ }^{35} \mathrm{Cl}$. In all cases a classical $4 \mathrm{~mm}$ probehead allowing spinning rates up to $10 \mathrm{kHz}$ was used. ${ }^{13} \mathrm{C}$ and ${ }^{15} \mathrm{~N}$ NMR chemical shifts are given relative to tetramethylsilane and neat nitromethane, respectively (precision $0.5 \mathrm{ppm}$ ). The spectra were recorded by use of cross-polarization (CP) from protons (contact time $2 \mathrm{~ms}$ ) and magic angle spinning (MAS). Before recording each spectrum it was checked that there was a sufficient delay between the scans allowing a full relaxation of the protons (typically $10 \mathrm{~s}$ ). The ${ }^{35} \mathrm{Cl}$ NMR spectra were recorded by use of a single pulse of $0.5 \mu \mathrm{s}$ (corresponding to $\pi / 12$ ). Typically 50000 to 100000 scans were accumulated with a recycle time of $1 \mathrm{~s}$. The chemical shifts are given relative to aqueous $\mathrm{NaCl}$.

FT-IR analysis was carried out at room temperature in the range $400-4000 \mathrm{~cm}^{-1}$ using a Nicolet IR 200 FT-IR infrared spectrometer.

\section{Results and discussion}

\subsection{X-ray diffraction study}

The unit formula of $\left(4-\left(\mathrm{OCH}_{3}\right) \mathrm{C}_{6} \mathrm{H}_{4} \mathrm{CH}_{2} \mathrm{NH}_{3}\right) \cdot\left[\mathrm{NO}_{3}\right]$ (I), contains one inorganic nitrate anion and one 4-methoxybenzylammonium cation (Fig. 1). This compound crystallizes in the orthorhombic space group Pnma $(Z=4)$. The atomic arrangement of this compound consists of inorganic layers, built from the $\mathrm{NO}_{3}^{-}$anions and the $-\mathrm{NH}_{3}^{+}$groups, interconnected by $\mathrm{N}-\mathrm{H} \cdots \mathrm{O}$ hydrogen bonds (Fig. S1, Table 2), extending parallel to the c-axis direction and

Table 1

Crystal data and structure refinement of $\left(\mathrm{C}_{8} \mathrm{H}_{12} \mathrm{NO}\right) \cdot\left[\mathrm{NO}_{3}\right](\mathbf{I})$ and $\left(\mathrm{C}_{8} \mathrm{H}_{14} \mathrm{~N}_{4}\right) \cdot\left[\mathrm{ClO}_{4}\right]_{2}$ (II).

\begin{tabular}{|c|c|c|}
\hline Empirical formula & $\left(\mathrm{C}_{8} \mathrm{H}_{12} \mathrm{NO}\right)\left[\mathrm{NO}_{3}\right](\mathrm{I})$ & $\left(\mathrm{C}_{8} \mathrm{H}_{14} \mathrm{~N}_{4}\right)\left[\mathrm{ClO}_{4}\right]_{2}(\mathrm{II})$ \\
\hline Formula weight $\left[\mathrm{g} \mathrm{mol}^{-1}\right]$ & 200.20 & 365.13 \\
\hline Crystal color, habit & Prism, colorless & Prism, colorless \\
\hline Crystal temperature $[\mathrm{K}]$ & 293 & 293 \\
\hline Crystal size $[\mathrm{mm}]$ & $0.55 \times 0.26 \times 0.08$ & $0.52 \times 0.22 \times 0.15$ \\
\hline Radiation, wavelength $[\AA ̊]$ & $\operatorname{MoK} \alpha, 0.71073$ & $\operatorname{MoK} \alpha, 0.71073$ \\
\hline Crystal system & Orthorhombic & Monoclinic \\
\hline Space group & Pnma & $P 2_{1} / c$ \\
\hline Unit-cell dimensions: & $\begin{array}{l}\mathrm{a}=15.7908(7) \AA \\
\mathrm{b}=6.8032(3) \AA \\
\mathrm{c}=8.7091(4) \AA\end{array}$ & $\begin{array}{l}\mathrm{a}=10.7978(14) \AA \\
\mathrm{b}=7.3297(10) \AA \\
\mathrm{c}=21.1861(19) \AA \\
\beta=120.641(4)^{\circ}\end{array}$ \\
\hline Volume $\left[\AA^{3}\right]$ & $935.60(7)$ & $1442.7(3)$ \\
\hline$Z$ & 4 & 4 \\
\hline Density calc. $\left[\mathrm{g} \mathrm{cm}^{-3}\right]$ & 1.421 & 1.681 \\
\hline Reflections for cell determination & 25 & 25 \\
\hline$\theta$-range for cell determination $\left[{ }^{\circ}\right]$ & $8-10$ & $8-10$ \\
\hline Absorption coefficient $\mu\left[\mathrm{mm}^{-1}\right]$ & 0.12 & 0.50 \\
\hline $\mathrm{F}(000)$ & 424 & 752 \\
\hline$\theta$-Range for data collection $\left[{ }^{\circ}\right]$ & $3-28$ & $3-28$ \\
\hline Limiting indices & $\begin{array}{l}-20 \leq \mathrm{h} \leq 20 \\
-8 \leq \mathrm{k} \leq 8 \\
-11 \leq \mathrm{l} \leq 11\end{array}$ & $\begin{array}{l}-14 \leq \mathrm{h} \leq 14 \\
-9 \leq \mathrm{k} \leq 9 \\
-27 \leq \mathrm{k} \leq 27\end{array}$ \\
\hline Reflections collected/unique & $\left(R_{\text {int }}=0.027\right)$ & $\left(R_{\text {int }}=0.039\right)$ \\
\hline Refinement method & Full matrix least-squares on $F^{2}$ & Full matrix least squares on $F^{2}$ \\
\hline Data, restrains, parameters $(\mathrm{I}>2 \sigma)$ & $1057,4,92$ & $2981,3,209$ \\
\hline Goodness-of-fit on $F^{2}$ & 1.09 & 1.04 \\
\hline $\mathrm{R}$ indices (all data, on $F^{2}$ ) & $\mathrm{R}=0.038, \mathrm{w} R=0.115$ & $\mathrm{R}=0.044, \mathrm{w} R=0.132$ \\
\hline$\Delta_{\rho}(\min , \max )\left[\mathrm{e} \AA^{-3}\right]$ & -0.28 and 0.21 & -0.47 and 0.74 \\
\hline
\end{tabular}



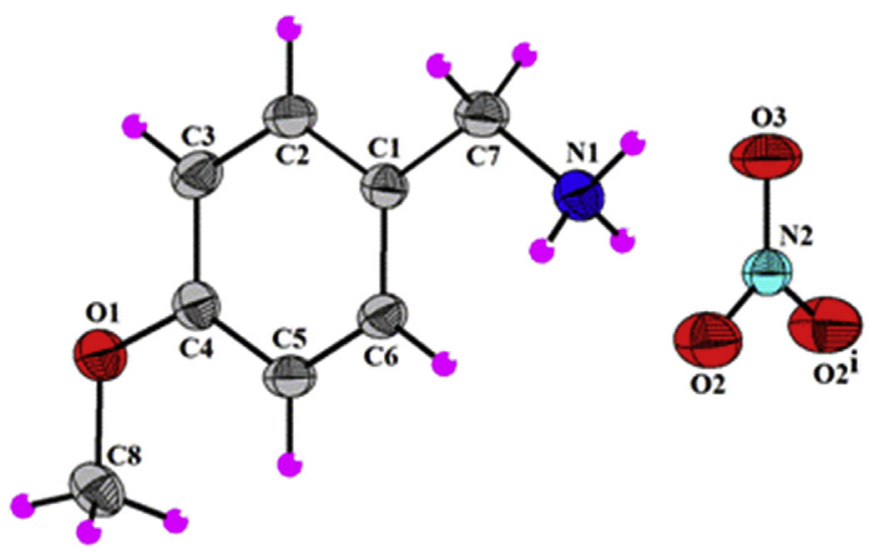

Fig. 1. View of the asymmetric unit of $\left(\mathrm{C}_{8} \mathrm{H}_{12} \mathrm{NO}\right) \cdot\left[\mathrm{NO}_{3}\right]$ (I). Displacement ellipsoids are drawn at the $40 \%$ probability level and $\mathrm{H}$ atoms are shown as small spheres of arbitrary radii.

Table 2

Hydrogen-bond geometry $\left(\AA,^{\circ}\right)$ for of $\left(\mathrm{C}_{8} \mathrm{H}_{12} \mathrm{NO}\right) \cdot\left[\mathrm{NO}_{3}\right](\mathrm{I})$ and $\left(\mathrm{C}_{8} \mathrm{H}_{14} \mathrm{~N}_{4}\right) \cdot\left[\mathrm{ClO}_{4}\right]_{2}$ (II).

\begin{tabular}{|c|c|c|c|c|}
\hline$D-\mathrm{H} \cdots A$ & $D-\mathrm{H}$ & $\mathrm{H} \cdots A$ & $D \cdots A$ & $D-\mathrm{H} \cdots A$ \\
\hline \multicolumn{5}{|c|}{$\left(\mathrm{C}_{8} \mathrm{H}_{12} \mathrm{NO}\right) \cdot\left[\mathrm{NO}_{3}\right](\mathrm{I})$} \\
\hline $\mathrm{N} 1-\mathrm{H} 1 A \cdots \mathrm{O} 2^{\mathrm{i}}$ & $0.91(1)$ & $1.99(1)$ & $2.898(14)$ & $176(1)$ \\
\hline $\mathrm{N} 1-\mathrm{H} 1 B \cdots \mathrm{N} 2^{\mathrm{ii}}$ & $0.91(1)$ & $2.58(1)$ & $3.443(2)$ & $160(2)$ \\
\hline $\mathrm{N} 1-\mathrm{H} 1 B \cdots \mathrm{O} 2^{\mathrm{ii}}$ & $0.91(1)$ & $2.25(1)$ & $3.016(17)$ & $142(1)$ \\
\hline $\mathrm{C} 3-\mathrm{H} 3 \cdots \mathrm{O} 3^{\mathrm{iv}}$ & 0.93 & 2.58 & $3.242(2)$ & 128 \\
\hline $\mathrm{C} 8-\mathrm{H} 8 B \cdots \mathrm{N} 2^{\mathrm{v}}$ & $0.98(1)$ & $2.60(1)$ & $3.561(2)$ & $167(2)$ \\
\hline \multicolumn{5}{|c|}{$\left(\mathrm{C}_{8} \mathrm{H}_{14} \mathrm{~N}_{4}\right) \cdot\left[\mathrm{ClO}_{4}\right]_{2}$ (II) } \\
\hline $\mathrm{N} 2-\mathrm{H} 2 \cdots \mathrm{O} 8^{\mathrm{i}}$ & $0.86(1)$ & $2.11(1)$ & $2.932(3)$ & $161(2)$ \\
\hline $\mathrm{N} 4-\mathrm{H} 4 A \cdots \mathrm{O} 7^{\mathrm{ii}}$ & $0.90(1)$ & $2.10(1)$ & $2.969(3)$ & $164(2)$ \\
\hline $\mathrm{N} 4-\mathrm{H} 4 A \cdots \mathrm{O} 7^{\mathrm{iii}}$ & $0.90(1)$ & $2.53(2)$ & $3.052(3)$ & $117(2)$ \\
\hline $\mathrm{N} 4-\mathrm{H} 4 B \cdots \mathrm{O} 5$ & $0.90(1)$ & $2.02(1)$ & $2.883(3)$ & $161(2)$ \\
\hline $\mathrm{C} 2-\mathrm{H} 2 A \cdots \mathrm{O} 7^{\mathrm{iv}}$ & 0.93 & 2.65 & $3.503(3)$ & 153 \\
\hline $\mathrm{C} 3-\mathrm{H} 3 \cdots \mathrm{O} 3^{v}$ & 0.93 & 2.61 & $3.334(4)$ & 135 \\
\hline $\mathrm{C} 5-\mathrm{H} 5 A \cdots \mathrm{O}^{\mathrm{i}}$ & 0.97 & 2.46 & $3.420(3)$ & 169 \\
\hline $\mathrm{C} 6-\mathrm{H} 6 A \cdots \mathrm{O} 1^{\mathrm{i}}$ & 0.97 & 2.64 & $3.420(3)$ & 137 \\
\hline $\mathrm{C} 6-\mathrm{H} 6 A \cdots \mathrm{O} 3^{\mathrm{i}}$ & 0.97 & 2.62 & $3.531(3)$ & 157 \\
\hline $\mathrm{C} 6-\mathrm{H} 6 B \cdots \mathrm{O} 1^{\mathrm{ii}}$ & 0.97 & 2.52 & $3.255(3)$ & 132 \\
\hline $\mathrm{C} 7-\mathrm{H} 7 A \cdots \mathrm{O} 2^{\mathrm{iv}}$ & 0.97 & 2.55 & $3.208(3)$ & 126 \\
\hline $\mathrm{C} 7-\mathrm{H} 7 A \cdots \mathrm{O} 6^{\mathrm{iii}}$ & 0.97 & 2.55 & $3.317(4)$ & 137 \\
\hline
\end{tabular}

Equivalent positions (I): (i) $x,-y+1 / 2, z$; (ii) $-x+1 / 2,-y+1, z-1 / 2$; (iii) $-x+1 / 2, y-1 /$ $2, z-1 / 2$; (iv) $-x+1,-y+1,-z$; (v) $-x+1,-y+1,-z+1$.

Equivalent positions (II): (i) $-x+1, y-1 / 2,-z+1 / 2$; (ii) $x, y-1, \quad z$; (iii) $-x+1,-y+1,-z$; (iv) $-x,-y+1,-z$; (v) $-x, y-1 / 2,-z+1 / 2$.

located at $\mathrm{x}=1 / 4$ and $\mathrm{x}=3 / 4$ (Fig. 2). The organic entities are anchored between these layers and connect them via $\mathrm{C}-\mathrm{H} \cdots \mathrm{O}$ and $\mathrm{C}-\mathrm{H} \cdots \mathrm{N}$ hydrogen bonds to form an infinite three-dimensional network (Fig. 2, Table 2).

The unit formula of compound (II), (2-(1- $\left.\left.\mathrm{C}_{4} \mathrm{H}_{9} \mathrm{~N}_{2}\right) \mathrm{C}_{4} \mathrm{H}_{5} \mathrm{~N}_{2}\right)$. $\left[\mathrm{ClO}_{4}\right]_{2}$, contains two inorganic perchlorate anions and one [2-(1$\left.\left.\mathrm{C}_{4} \mathrm{H}_{9} \mathrm{~N}_{2}\right) \mathrm{C}_{4} \mathrm{H}_{5} \mathrm{~N}_{2}\right]^{2+}$ dication (Fig. 3). This compound crystallizes in the monoclinic space group $P 2_{1} / c(Z=4)$. In the atomic arrangement, the organic cations are inserted between the mineral anions via $\mathrm{N}-\mathrm{H} \cdots \mathrm{O}$ and $\mathrm{C}-\mathrm{H} \cdots \mathrm{O}$ hydrogen bonds ensuring the cohesion and the stability of the crystalline edifice so as to generate a threedimensional structure (Fig. 4). It should be noted that the $\mathrm{Cl}(2) \mathrm{O}_{4}$ groups are connected to the $-\mathrm{NH}_{2}^{+}$ions via $\mathrm{N}-\mathrm{H} \cdots \mathrm{O}$ hydrogen bonds to form ribbons propagating along the $b$-axis direction at (1/ $2,0,0)$ and $(1 / 2,0,1 / 2)$ (Fig. 6 , Table 4 ). Within the ribbons, various graph-set motifs are recognizable, including $\mathrm{R}_{2}^{4}(12)$ and $\mathrm{R}_{2}^{2}(4)$ rings (Fig. S2).

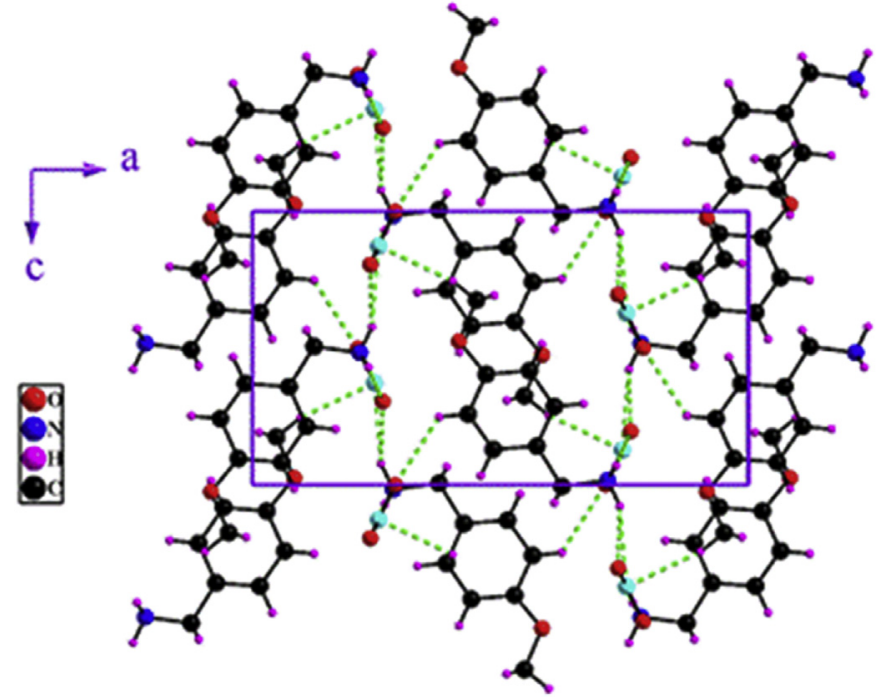

Fig. 2. Projection along the $b$ axis of the atomic arrangement of $\left(\mathrm{C}_{8} \mathrm{H}_{12} \mathrm{NO}\right) \cdot\left[\mathrm{NO}_{3}\right](\mathbf{I})$.

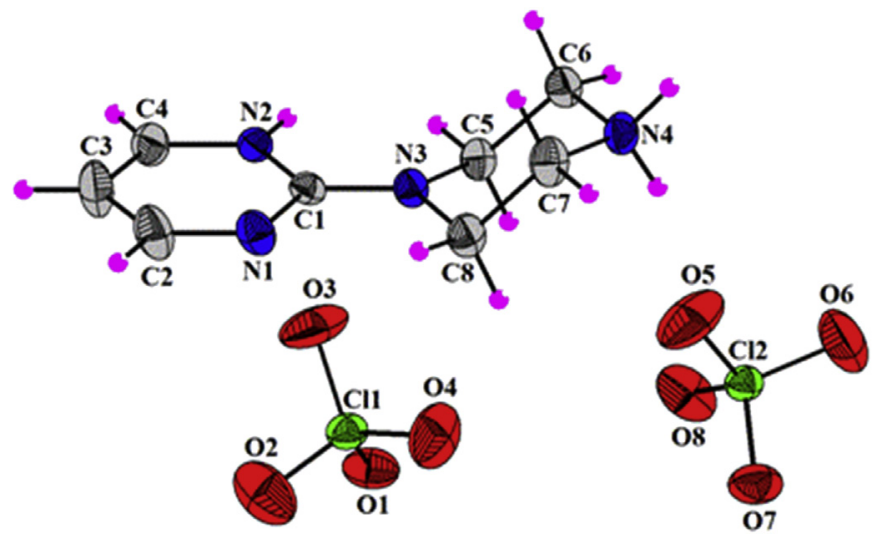

Fig. 3. View of the asymmetric unit of $\left(\mathrm{C}_{8} \mathrm{H}_{14} \mathrm{~N}_{4}\right) \cdot\left[\mathrm{ClO}_{4}\right]_{2}$ (II). Displacement ellipsoids are drawn at the $40 \%$ probability level and $\mathrm{H}$ atoms are shown as small spheres of arbitrary radii.

The conformation of the piperazine six-membered ring can be described in terms of Cremer and Pople puckering coordinates [25], i.e., evaluating the parameters $Q$ (total puckering amplitude), $q_{2}, q_{3}$, $\theta$ and $\varphi$. The calculated values are as follows: $Q=0.5655 \AA$, $q_{2}=0.0247 \AA$, $q_{3}=0.5650 \AA ., \theta=2.51^{\circ}$ and $\varphi=-94.08^{\circ}$.

\subsection{Hirshfeld surfaces and fingerprint plot analysis of the} intermolecular hydrogen bond interactions for both compounds (I) and (II)

The nature of intermolecular interactions existing in compounds (I) and (II) were examined using Hirshfeld surface plots generated using the CrystalExplorer software [26]. The Hirshfeld surfaces represent the partition into molecular fragments of the total crystalline electron density [27]. The Hirshfeld surface is an extension of the Hirshfeld concept which divides the electron density of a molecule into continuous atomic fragments. In analogy with this concept a molecule in a crystal is defined by a weight function: 


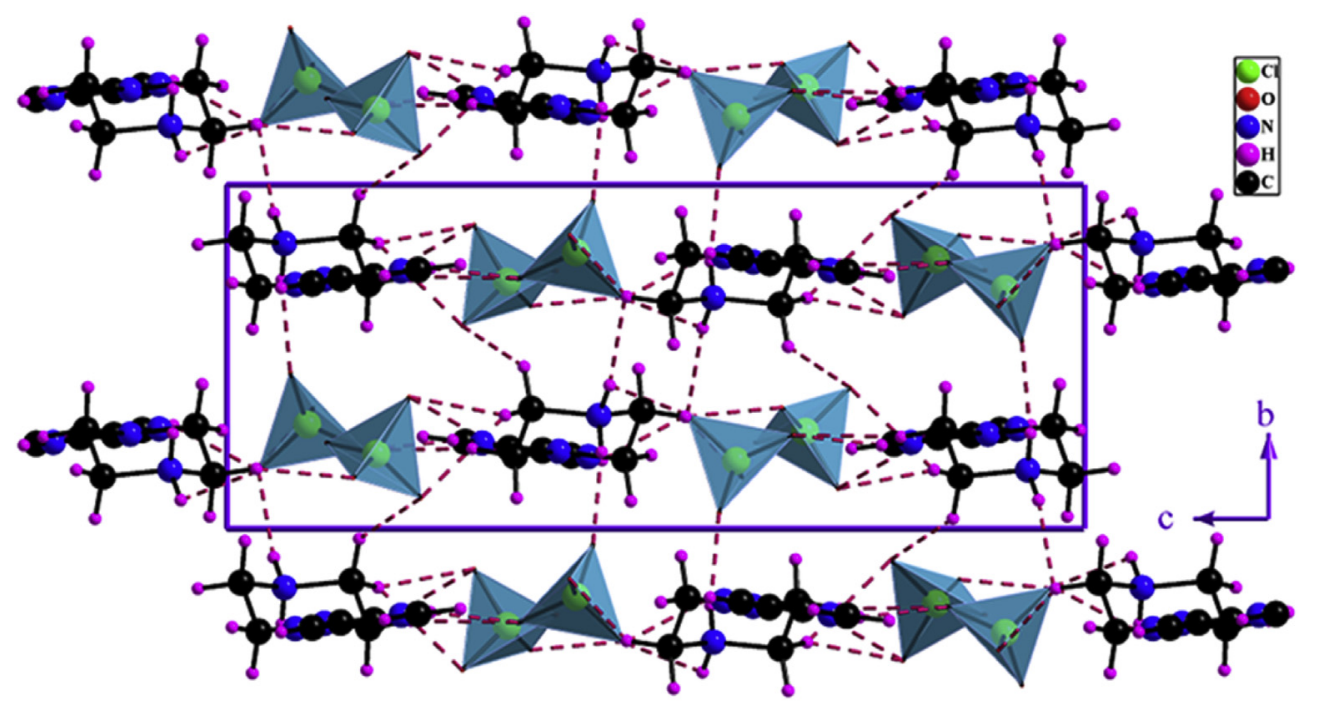

Fig. 4. Projection along the an axis of the atomic arrangement of $\left(\mathrm{C}_{8} \mathrm{H}_{14} \mathrm{~N}_{4}\right) \cdot\left[\mathrm{ClO}_{4}\right]_{2}$ (II). A polyhedral representation is used for $\mathrm{ClO}_{4}$

$$
\begin{aligned}
w(r) & =\sum_{i \in \text { molecule }} \rho_{i}(r) / \sum_{i \in \text { crystal }} \rho_{i}(r) \\
& =\rho_{\text {promolecule }}(r) / \rho_{\text {procrystal }}(r)
\end{aligned}
$$

where $\rho(r)$ is a spherically averaged Hartree-Fock atomic electron density function centered at the nucleus, and the pro-molecule and pro-crystal are the sums over the atoms belonging to a single molecule and the crystal, respectively. The $w(r)$ function is cut off at $0.5 \AA$ which ensures a maximum proximity of neighboring molecular volumes and prevents overlap. A typical molecular Hirshfeld surface contains tens of thousands of individual points, each having a well-defined $d_{i}$ and $d_{e}$ pair $[28,29]$. $d_{i}$ represents the distance from the surface to the nearest atom in the molecule itself, and $d_{e}$ the distance to the nearest atom outside the molecule. As such, they reveal details of close contacts between molecules, especially in the vicinity of hydrogen bonds. The enrichment ratios [30] of contacts between the different chemical species were computed in order to highlight which contacts are favored and are likely to be the crystal driving force. The red spots on the surface represent $\mathrm{H} \cdots \mathrm{O}$ contacts to neighboring molecules which correspond to the $\mathrm{N}-\mathrm{H} \cdots \mathrm{O}$ and $\mathrm{C}-\mathrm{H} \cdots \mathrm{O}$ hydrogen bond interactions between the molecules inside the surface and the molecules which surround it. In fact, three $\mathrm{N}-\mathrm{H} \cdots \mathrm{O}$ and one $\mathrm{C}-\mathrm{H} \cdots \mathrm{O}$ hydrogen bonds exist in the structure of compound (I) (Fig. 5). The $\mathrm{H} \cdots \mathrm{O}$ hydrogen bonds represent half of all the contact surface (50.4\%). They are enriched with $E=1.52$ and these favorable electrostatic interactions are an important contributor to the crystal stability (Figs. S3-a, Table 3). The $\mathrm{H} \cdots \mathrm{H}$ are the next most abundant interactions (26.3\%), but these contacts are mildly impoverished $(E=0.67)$ [31]. The $\mathrm{H} \cdots \mathrm{H}$ contacts are generated between the organic cations inside the surface and the other molecules outside the Hirshfeld surface (Fig. S3b, Table 3). The $\mathrm{H} \cdots \mathrm{C}$ contacts represent the third most important interaction surface (18.2\%) and are over-represented with higher enrichment ratio equal to 1.51 (Fig. S3c, Table 3 ). The $\mathrm{H} \cdots \mathrm{N}$ contacts are overrepresented with an enrichment value $E=1.60$, as there are two $\mathrm{N}-\mathrm{H} \cdots \mathrm{N}$ hydrogen bonds in the crystal structure of compound (I) (Fig. S3d, Table 2). The $\mathrm{C} \cdots \mathrm{O}$ and $\mathrm{O} \cdots \mathrm{O}$ contacts are impoverished with small enrichment values equal to 0.21 and 0.11 respectively [32].

Figure S4 illustrates the distribution of the percentages relative

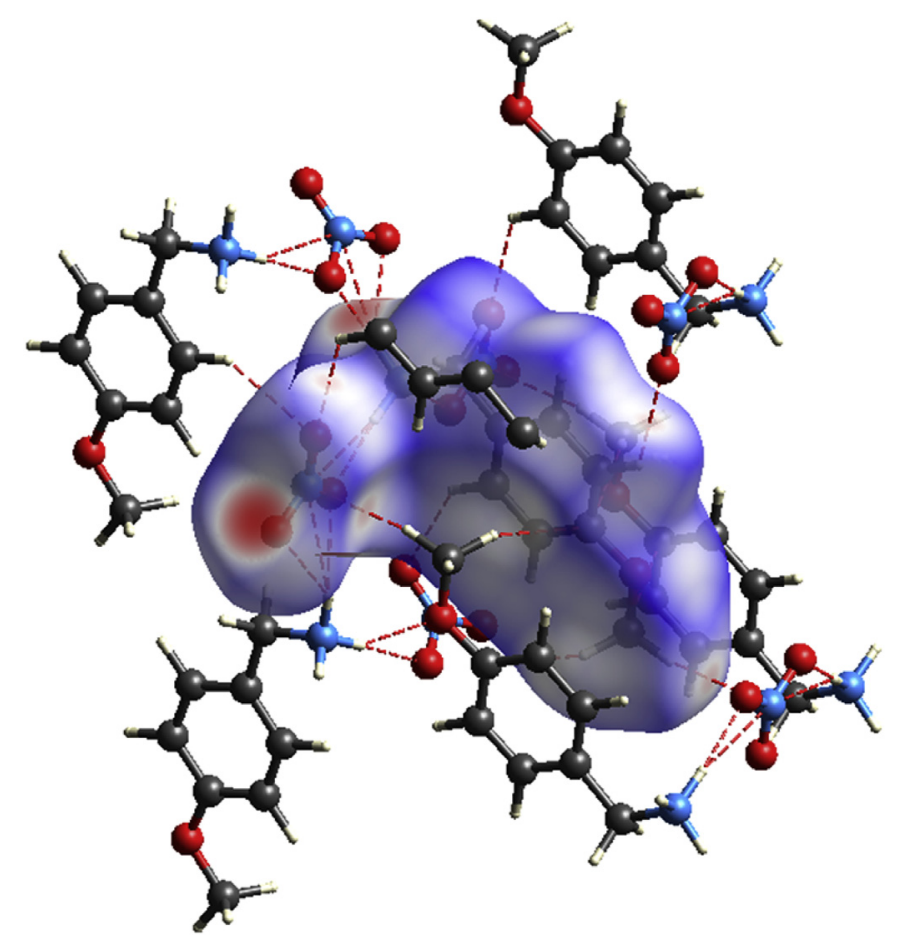

Fig. 5. View of the $d_{\text {norm }}$ quantity mapped on the Hirshfeld surface of the asymmetric unit of compound (I). The red color represents the area on the surface where the atoms make intermolecular contacts closer than the sum of their Van der Waals radii. (For interpretation of the references to color in this figure legend, the reader is referred to the Web version of this article.)

to the interactions existing in compound (I), showing the domination of the $\mathrm{H} \cdots \mathrm{O} / \mathrm{O} \cdots \mathrm{H}$ interactions. This suggests that these strong electrostatic attractions are the driving force of crystalline packing [33].

For compound (II), the visualization of the Hirshfeld threedimensional $d_{\text {norm }}$ surface (Fig. 6) reveals intensive red spots, which indicate the presence of $\mathrm{O}-\mathrm{H} \cdots \mathrm{O}$ hydrogen bonds. Indeed, four $\mathrm{N}-\mathrm{H} \cdots \mathrm{O}$ and eight $\mathrm{C}-\mathrm{H} \cdots \mathrm{O}$ hydrogen bonds exist in the crystal structure of compound (II). On the other hand, the $d_{\text {norm }}$ surface has light spots that correspond to $\mathrm{H} \cdots \mathrm{H}$ and $\mathrm{H} \cdots \mathrm{N}$ interactions with 
Table 3

Contacts, enrichment ratios, chemical proportions on the Hirshfeld surface, and major interaction types of compound (I).

\begin{tabular}{|c|c|c|c|c|c|c|}
\hline \multirow[t]{2}{*}{ Surface (\%) } & $\mathrm{H}$ & $\mathrm{C}$ & $\mathrm{O}$ & $\mathrm{N}$ & & \\
\hline & 62.25 & 9.65 & 26.55 & 1.65 & & \\
\hline Major Contacts & $\mathrm{O} \cdots \mathrm{H}$ & $\mathrm{H} \cdots \mathrm{H}$ & $\mathrm{H} \cdots \mathrm{C}$ & $\mathrm{H} \cdots \mathrm{N}$ & $\mathrm{C} \cdots \mathrm{O}$ & $0 \cdots \mathrm{O}$ \\
\hline Proportion (\%) & 50.4 & 26.3 & 18.2 & 3.3 & 1.1 & 0.8 \\
\hline Enrichment $\left(E_{\mathrm{xx}} / E_{\mathrm{xy}}\right)$ & 1.52 & 0.67 & 1.51 & 1.60 & 0.21 & 0.11 \\
\hline
\end{tabular}

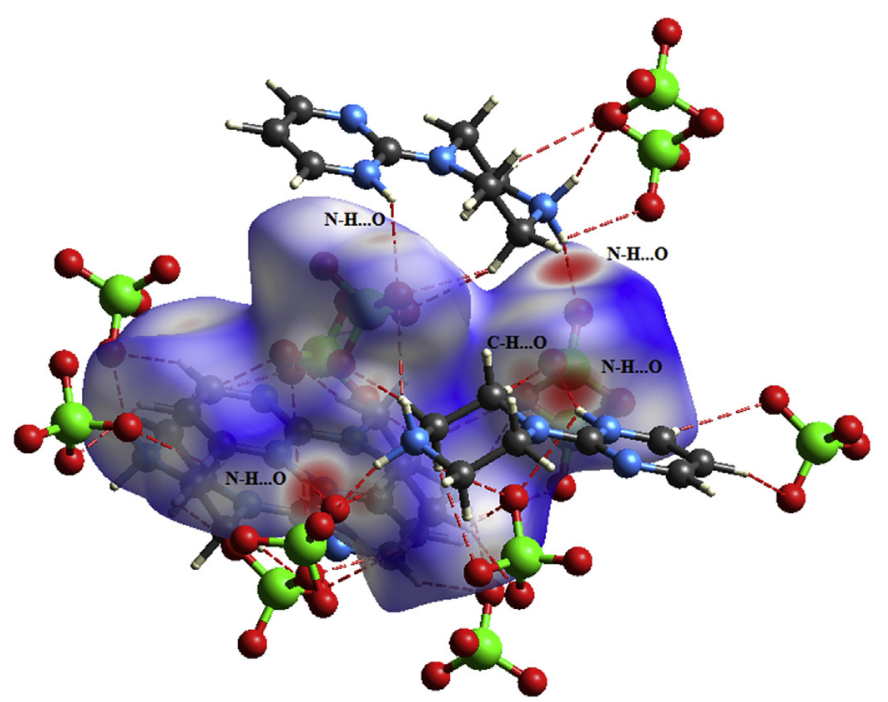

Fig. 6. View of the $d_{\text {norm }}$ quantity mapped on the Hirshfeld surface of the asymmetric unit of compound (II). The red color represents the area on the surface where the atoms make intermolecular contacts closer than the sum of their Van der Waals radii. (For interpretation of the references to color in this figure legend, the reader is referred to the Web version of this article.)

organic molecules. Globally, $\mathrm{H} \cdots \mathrm{O} / \mathrm{O} \cdots \mathrm{H}$ intermolecular interactions are the most abundant contacts which connect the organic cations with the perchlorate anions. This type of interaction represents more than the half of all the contact surface (70\%) and is enriched with an enrichment ratio around 1.63 (Figs. S5-a, Table 4). This suggests that these strong electrostatic attractions are the driving force in the crystal packing formation [33].

The $\mathrm{H} \cdots \mathrm{H}$ contacts are the second most frequent contacts with a percentage of $14.1 \%$ due to the abundance of molecular hydrogen on the molecular surface $(52.8 \%)$ but this type of interaction is under-represented with an enrichment ratio equal to 0.50 (Fig. S5b, Table 4), reflecting the attraction of organic cations with each other. The $\mathrm{H} \cdots \mathrm{N}$ contacts represent $4 \%$ of all contacts and they are also over-represented with an enrichment ratio equal to 1.16 (Table 4). The $C \cdots O$ contacts are enriched with an enrichment value greater than unity $\left(\mathrm{E}_{C} \ldots \mathrm{O}=1.27\right)$. The $\mathrm{H} \cdots \mathrm{C}$ and $\mathrm{O} \cdots \mathrm{N}$ contacts are moderately enriched as the enrichment ratios are close to unity (0.91 and 0.95 respectively). The auto-contacts $0 \cdots 0$ are

Table 4

Enrichment ratios, chemical proportions on the Hirshfeld surface, and major interaction types of compound (II).

\begin{tabular}{|c|c|c|c|c|c|}
\hline Atomes & $\mathrm{Cl}$ & $\mathrm{H}$ & 0 & $\mathrm{~N}$ & $C$ \\
\hline$\%$ surface & 0 & 52.8 & 40.45 & 3.25 & 3.5 \\
\hline$E C l \ldots$ & 0 & 0 & 0 & 0 & 0 \\
\hline$E \mathrm{H}$. & & 0.50 & 1.63 & 1.16 & 0.91 \\
\hline$E O \ldots$ & & & 0.14 & 0.95 & 1.27 \\
\hline$E C \ldots$ & & & & 0 & 0 \\
\hline
\end{tabular}

impoverished as they are electrostatically repulsive.

Figure S6 shows also the different percentages of the intermolecular contacts in compound (II) and shows clearly the great dominance of the $\mathrm{O} \cdots \mathrm{H} / \mathrm{H} \cdots \mathrm{O}$ contacts.

\subsection{HOMO-LUMO analysis for compounds (I) and (II)}

Calculation of the HOMO/LUMO energy levels are very helpful to predict the chemical behavior of the desired compound. HOMOLUMO orbitals were calculated from the crystal Data with the DFT-B3LYP/6-311 $++\mathrm{G}^{* *}$ method for compounds (I) and (II) using the Gaussian 09 software [34] and are displayed in Fig. 7 (a \& b). For compound (I), the highest occupied molecular orbital (HOMO) is located mainly on a nitrate anion which behaves as an electron donor with a calculated energy of $-0.148 \mathrm{eV}$, while the lowest unoccupied molecular orbitals (LUMO) is concentrated on the methyl group of the organic molecule which behaves as an electron acceptor with a calculated energy of $2.907 \mathrm{eV}$. The global chemical descriptors of the compound (I) are: ionization potential $(\mathrm{I})=-$ $\mathrm{E}_{\mathrm{HOMO}}=0.148$, electron affinity $(\mathrm{A})=-\mathrm{E}_{\mathrm{LUMO}}=-2.907$, chemical potential $(\mu)=-(I+A) / 2=1.379$, the global hardness $(\eta)=(I-A) /$ $2=1.527$, softness $(\nu)=1 / \eta=0.65$, electronegativity $(\chi)=(I+A) /$ $2=-1.379$ and electrophilicity index $(\omega)=\mu^{2} / 2 \eta=0.62$. A large HOMO-LUMO energy gap indicate that the compound is "hard" while a small HOMO-LUMO energy gap indicates that the compound is "Soft". The large energy gap between the HOMO and LUMO orbitals in compound (I) is $3.055 \mathrm{eV}$ and implies a good stability and a high chemical hardness for the compound (I) [35]. In compound (II), the HOMO orbital is located on a perchlorate anion while the LUMO orbital is localized on the aromatic ring of the organic molecule. The different characteristics deduced from these values are: Ionization potential $(\mathrm{I})=-\mathrm{E}_{\mathrm{HOMO}}=4.455$, electron affinity $(A)=-E_{\text {LUMO }}=2.136$, chemical potential $(\mu)=-(I+A) /$ $2=-3.295$, global hardness $(\eta)=(\mathrm{I}-\mathrm{A}) / 2=1.159$, softness $(\nu)=1 /$ $\eta=0.86$, electronegativity $(\chi)=(I+A) / 2=3.295$ and electrophilicity index $(\omega)=\mu^{2} / 2 \eta=4.683$. The large energy gap between the HOMO and LUMO orbitals in the compound (II) is $2.319 \mathrm{eV}$, suggesting that the compound (II) is kinetically also stable molecule and has a high chemical reactivity because it is energetically favorable to add electron to a high-lying LUMO and to extract electrons from low-lying HOMO [36]. The energy distribution of the different orbitals for both compounds are shown in Fig. S7 (a \& b).

\subsection{Molecular Electrostatic Potential analysis (MEP)}

The MEP maps for both compound are shown in Fig. 8 ( $a \& b$ ). The MEP is used to determine the nuclear and electronic charge distribution of a given molecule. The maps were obtained at the B3LYP/6-311G ${ }^{++}(\mathrm{d}, \mathrm{p})$ level of theory. Moreover, blue and red colors indicate the positive and negative potentials, respectively. As it can be seen from Fig. 8 a, the electrostatic potential maps are colorcoded and are subdivided into many regions where those various colors are used to identify different potentials. Intermediate potentials are assigned to colors according to the following color spectrum: red $<$ orange $<$ yellow $<$ green $<$ blue. This figure 
(a)

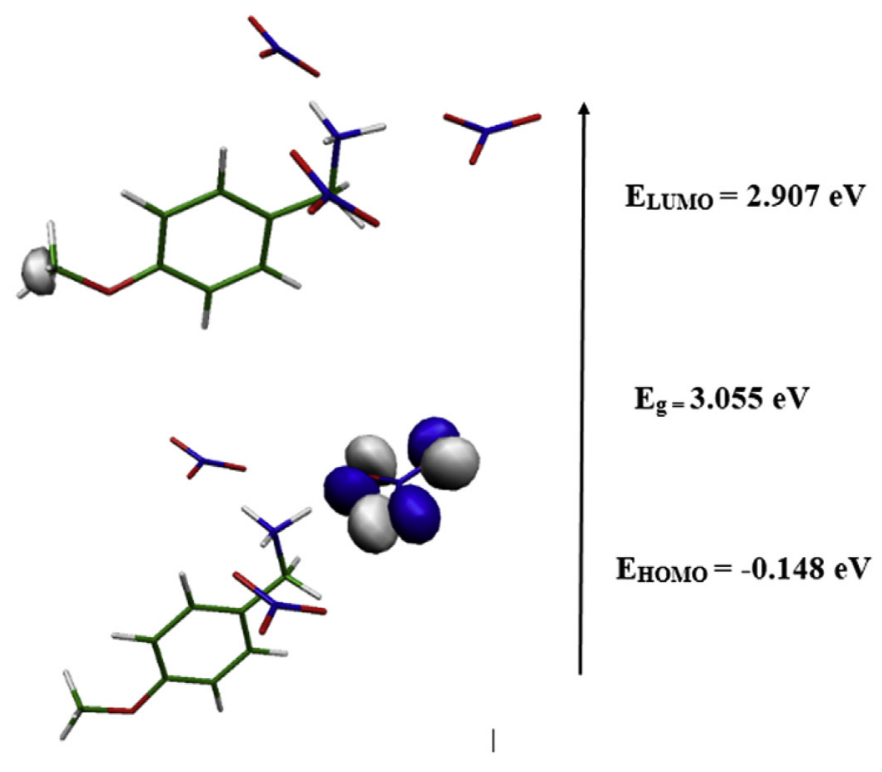

(b)

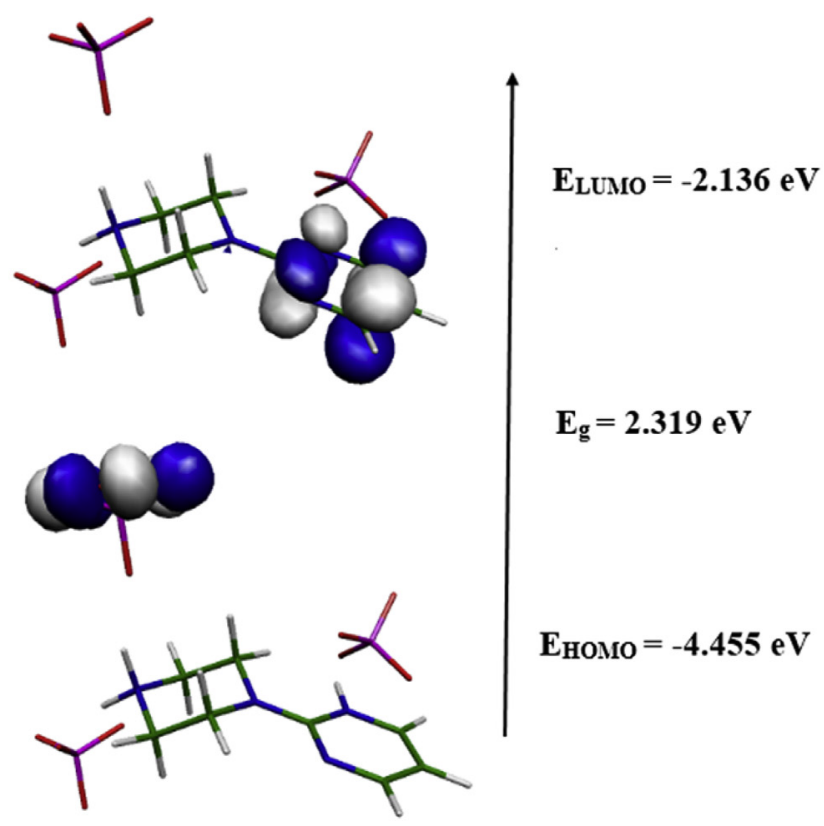

Fig. 7. Frontier molecular orbitals (HOMO and LUMO) of compounds (I) and (II).

demonstrates the electronic transfer between the $\mathrm{NO}_{3}$ anion and the organic molecule of the compound (I). The positive region is localized on the $\mathrm{NH}_{3}$ group while the negative region is located on the oxygen. When the nitrate anions are taken into account, the $\mathrm{NH}_{3}$ group is enriched in electrons, the less rich part is around the aromatic carbon. For compound (II), Fig. 8 b demonstrates also the electronic transfer between the $\mathrm{ClO}_{4}$ anions and the organic molecule. The positive region is located on the $\mathrm{NH}_{2}$ group and the negative region is localized on the aromatic ring. When we take into account the perchlorate anions, the aromatic ring becomes more deficient in electrons. The transfer is sharper with the distribution of charges.

\subsection{Mulliken population analysis}

The Mulliken charge transfer of atomic orbitals [37,38] was obtained using the B3LYP method with the $6-311 \mathrm{G}^{++}(\mathrm{d}, \mathrm{p})$ basis set. The charge distribution of all atoms in compound (I) is shown in Table 5. All hydrogen atoms carry positive charge in the range $0.144-0.363$. The atomic charge distribution shows the two carbon atoms have positive charges (C3: 0.420 and C7: 0.091 for compound (I) and C2: 0.20, C4: 0.34 and N3: 0.23 for compound (II)) while the other atoms ( $\mathrm{C} 1, \mathrm{C} 2, \mathrm{C} 4, \mathrm{C} 5, \mathrm{C} 6, \mathrm{C} 8, \mathrm{O}, \mathrm{N}$ for compound (I) and $\mathrm{C} 1, \mathrm{C} 3$, $\mathrm{C} 5, \mathrm{C} 6, \mathrm{C} 7, \mathrm{C} 8, \mathrm{~N} 1, \mathrm{~N} 2$ and $\mathrm{N} 4$ for compound (II)) have negative charges.

For compound (I), the three nitrate ions interacting with the $\mathrm{NH}_{3}$ group were taken into account in order to see the electronic transfer between the organic and inorganic parts. When we count all the charges on the organic molecule, we found $(+1)$ for the organic molecule but only $(+0.888)$ for the system with the nitrate anions, which means that these last ones have transferred 0.112 electron. This transfer is essentially on the benzene ring.

For compound (II), when we count all the charges on the organic molecule, we found $(+1)$ for the organic molecule but only +0.621 for the system where we take the perchlorate anions into account, which means that these last ones transferred 0.38 electron. This transfer is essentially on the benzene ring and more particularly on the $\mathrm{C} 3$ and $\mathrm{C} 8$ carbon atoms (Table 5).

\subsection{NMR results}

For compound (I), two ${ }^{13} \mathrm{C} C \mathrm{CP}-\mathrm{MAS}$ NMR spectra were recorded, the first one with a contact time of $2 \mathrm{~ms}$ to see all carbons (Figs. S8-a) and the second one with a contact time of $150 \mu$ s to preferentially see the carbons directly linked to protons (Figs. S8-b). It can then be deduced that the peaks at 158 and $124 \mathrm{ppm}$ correspond to carbons that are not bound to protons, their intensity being much lower. In the resonance zone of aliphatic carbons, the spectrum has two sharp lines at $41.6 \mathrm{ppm}$ and $50.5 \mathrm{ppm}$ corresponding respectively to the methylenic and methoxylic carbons. In the resonance region of aromatic carbons, between 110 and $160 \mathrm{ppm}$, the spectrum contains five peaks. The other peaks are the spinning side bands of the aromatic carbons. This number of NMR components proves the presence of a single organic entity in the asymmetric unit of the compound, which is in full agreement with the crystallographic data.

The ${ }^{15} \mathrm{~N}$ CP-MAS NMR spectrum of compound (I), presented in Fig. S9, is in good agreement with the structure determined by Xray diffraction. It exhibits two well resolved peaks at 375.1 and $-24.8 \mathrm{ppm}$, corresponding to the two crystallographically independent nitrogen sites, which proves the presence of a single organic moiety in the asymmetric unit of the compound.

The ${ }^{13} \mathrm{C}$ CP-MAS NMR spectrum obtained for compound (II) is displayed on Fig. S10. It shows four well resolved resonance peaks between 109 and $168 \mathrm{ppm}$ corresponding to the four aromatic carbon atoms of the organic cation. This proves the presence of a single organic entity in the asymmetric unit of the compound, a result in good agreement with the crystallographic data. In the resonance region of the aliphatic carbons, only two peaks are resolved corresponding to the four aliphatic carbon atoms of the piperazinium ring. This is probably due to the fact that the signals overlap in pairs.

The ${ }^{15} \mathrm{~N}$ CP-MAS NMR spectrum of compound (II) (Fig. S11), exhibits three peaks at $-251.9,-308.5$ and $-3.66 \mathrm{ppm}$ corresponding to the four nitrogen atoms of the organic cation. This number of NMR components, less than four, is consistent with the presence of a single organic entity in the asymmetric unit of the compound. 
(a) (b)
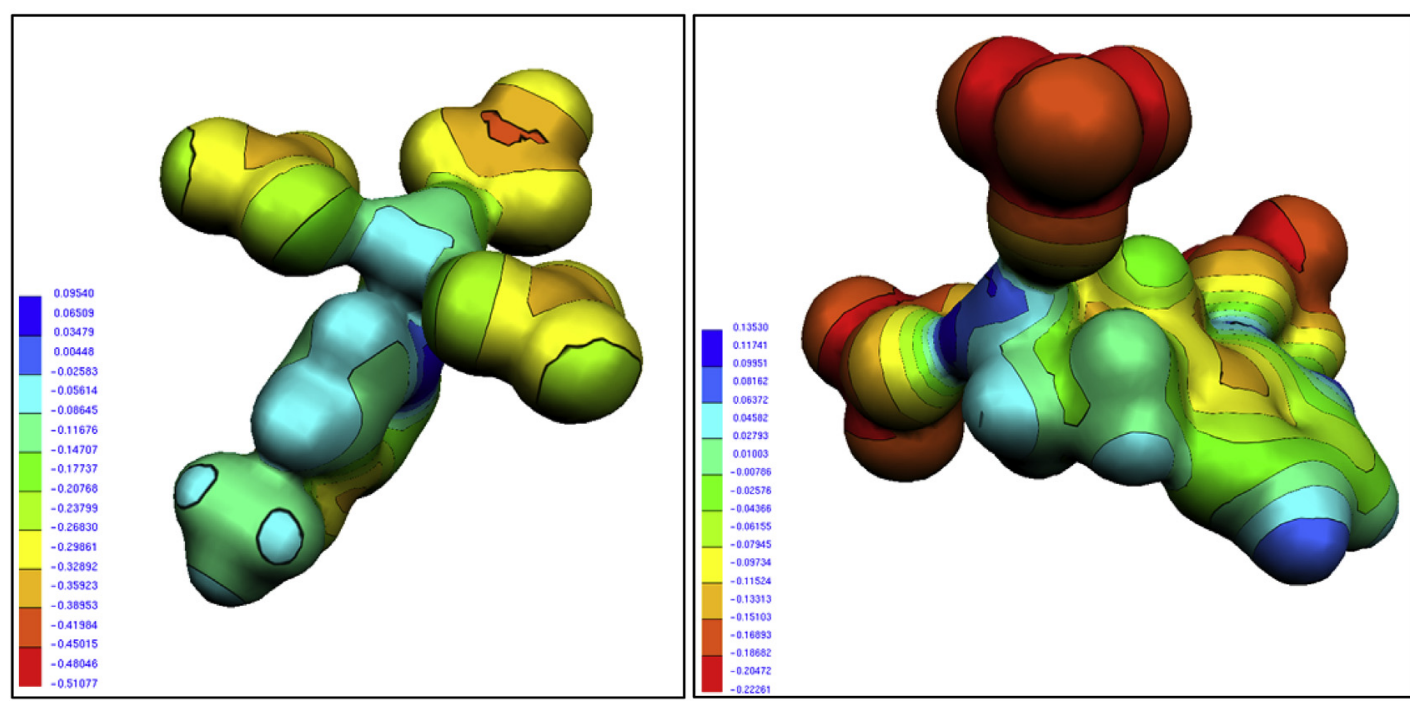

Fig. 8. Molecular Electrostatic Potential maps of the two compounds (I) (a) and (II) (b).

Table 5

Mulliken charge transfer in compound (I). For the numbering of atoms, see below.

\begin{tabular}{lll}
\hline Atoms & Cation charge & Cation + nitrate charge \\
\hline $\mathrm{O}$ & -0.141 & -0.176 \\
$\mathrm{~N}$ & -0.232 & -0.255 \\
$\mathrm{C} 1$ & -0.737 & -0.344 \\
$\mathrm{C} 2$ & -0.316 & -0.350 \\
$\mathrm{C} 3$ & +1.106 & +0.420 \\
$\mathrm{C} 4$ & +0.105 & -0.183 \\
$\mathrm{C} 5$ & -0.395 & -0.235 \\
$\mathrm{C} 6$ & -0.454 & -0.664 \\
$\mathrm{C} 7$ & -0.009 & +0.091 \\
$\mathrm{C} 8$ & -0.689 & -0.344 \\
$\mathrm{H}(\mathrm{C} 1)$ & +0.246 & +0.219 \\
& +0.246 & +0.219 \\
$\mathrm{H}(\mathrm{C} 2)$ & +0.163 & +0.150 \\
& +0.206 & +0.144 \\
$\mathrm{H}(\mathrm{C} 4)$ & +0.163 & +0.150 \\
$\mathrm{H}(\mathrm{C} 5)$ & +0.183 & +0.227 \\
$\mathrm{H}(\mathrm{C} 7)$ & +0.219 & +0.159 \\
$\mathrm{H}(\mathrm{C} 8)$ & +0.216 & +0.173 \\
$\mathrm{H}(\mathrm{N})$ & +0.045 & +0.143 \\
& +0.357 & +0.363 \\
& +0.361 & +0.351 \\
\hline
\end{tabular}

The ${ }^{35} \mathrm{Cl}$ MAS NMR spectrum obtained for compound (II) is displayed on (Fig. S12). It shows a signal corresponding to a perchlorate [39]. Its shape is typical for a quadrupolar nucleus and a simulation leads to the following parameters:

$$
\begin{array}{llll}
\text { For } \quad \mathrm{Cl}(1) \quad \text { atom, } & \delta_{\text {iso }}=1009.87 \mathrm{ppm}, & \text { etaQ }=0.84 & \text { and } \\
\text { nuQ }=247.97(\mathrm{kHz}) & & \\
\text { For } \mathrm{Cl}(2) \text { atom, } & \delta_{\text {iso }}=1004.92 \mathrm{ppm}, & \text { etaQ }=0.58 & \text { and } \\
\text { nuQ }=513.52(\mathrm{kHz}) & &
\end{array}
$$

Theoretical calculations were undertaken in order to assign the NMR resonances to the different crystallographic non-equivalent carbon atoms of the unit cell. The chemical shifts calculations were made on the organic molecules only. X-ray diffraction data give $\mathrm{C}-\mathrm{H}$ or $\mathrm{N}-\mathrm{H}$ distances which are too small compared to what is usually observed (typically below $0.1 \mathrm{~nm}$ ) due to the fact that this method is not sensitive to the nuclei but to the electrons and so gives values corresponding to distances between the barycenters of electronic charges. As a consequence, the positions of the hydrogen atoms were first optimized with the B3LYP/6-311++ $\mathrm{G}^{* *}$ method, the other atoms being frozen. Then the absolute chemical shifts were calculated using the GIAO method. Finally, the calculated

\begin{tabular}{|c|c|c|c|c|}
\hline \multirow[t]{2}{*}{ Atoms } & \multicolumn{2}{|l|}{ Organic molecule } & \multirow[t]{2}{*}{ Organic molecule + nitrate anion } & \multirow[t]{2}{*}{ Experiment } \\
\hline & Full optimisation & Proton optimisation & & \\
\hline $\mathrm{C} 1$ & 54.2 & 47.6 & 45.5 & 41.7 \\
\hline $\mathrm{C} 2$ & 57.9 & 57.6 & 56.0 & 50.5 \\
\hline $\mathrm{C} 3$ & 118.7 & 117.6 & 139.3 & 124 \\
\hline C4 & 132.6 & 131.0 & 134.9 & 126 \\
\hline $\mathrm{C} 5$ & 131.4 & 129.5 & 108.8 & 111 \\
\hline C6 & 172.2 & 171.3 & 161.2 & 158 \\
\hline $\mathrm{C} 7$ & 115.4 & 114.2 & 117.2 & 119 \\
\hline $\mathrm{C} 8$ & 121.1 & 119.3 & 131.2 & 124 \\
\hline $\mathrm{NH}_{3}$ & -365.7 & -366.5 & -362.3 & -375 \\
\hline $\mathrm{NO}_{3}$ & -14.3 & -14.3 & -16.6 & -25 \\
\hline
\end{tabular}
values were calibrated relative to tetramethylsilane with

Table 6

Comparison of calculated and experimental chemical shift values (ppm) of carbon atoms in (I). 
Table 7

Comparison of calculated and experimental chemical shift values (ppm) of carbon atoms in (II).

\begin{tabular}{|c|c|c|c|c|}
\hline \multirow[t]{2}{*}{ Atoms } & \multicolumn{2}{|l|}{ Organic molecule } & \multirow[t]{2}{*}{ Organic molecule + perchlorate anions } & \multirow[t]{2}{*}{ Experiment } \\
\hline & Full optimisation & Proton optimisation & & \\
\hline $\mathrm{C} 1$ & 157.4 & 154.3 & 155.8 & 152.4 \\
\hline $\mathrm{C} 2$ & 179.2 & 175.1 & 168.1 & 167.0 \\
\hline $\mathrm{C} 3$ & 123.1 & 117.6 & 108.6 & 109.8 \\
\hline $\mathrm{C} 4$ & 153.3 & 147.8 & 154.0 & 145.5 \\
\hline $\mathrm{C} 5$ & 44.1 & 44.9 & 43.0 & 41.9 \\
\hline C6 & 45.9 & 43.4 & 45.8 & 41.9 \\
\hline $\mathrm{C7}$ & 53.8 & 52.6 & 47.5 & 44.4 \\
\hline $\mathrm{C} 8$ & 51.3 & 47.7 & 48.8 & 44.4 \\
\hline N1 & -114.9 & -118.1 & -121.2 & $-128^{\mathrm{a}}$ \\
\hline N2 & -249.6 & -256.1 & -241.3 & -251.9 \\
\hline N3 & -298.9 & -301.3 & -282.6 & -308.5 \\
\hline N4 & -349.4 & -348.8 & -353.1 & -366.2 \\
\hline
\end{tabular}

a very weak peak that barely emerges from background noise.

$\delta_{\exp }=0 \mathrm{ppm}$. The atoms are labeled as depicted below:<smiles></smiles>

(I)<smiles></smiles>

(II)

The results are listed on Table 6 and Table 7. Clearly, there is a very good agreement between the experimental and theoretical values calculated after optimisation of the position of the protons, particularly when taking into account the hydrogen bonding interactions, allowing unambiguously the attribution of the different NMR signals.

\subsection{IR spectroscopy}

FT-IR spectroscopy is a widely used technique for the characterization of new solid phases. The IR spectra of compounds (I) and (II) are given in Figs. S13-a and S14-a, respectively. The characteristic vibrational modes of the two compounds can be compared to those of similar perchlorate and nitrate compounds [40,41].

The molecular structures of both compounds have various functional groups such as $\mathrm{NH}_{3}^{+}, \mathrm{NH}_{2}^{+}, \mathrm{N}-\mathrm{H}, \mathrm{C}-\mathrm{H}, \mathrm{C}-\mathrm{N}, \mathrm{C}=\mathrm{C}$ and $\mathrm{C}=$ $\mathrm{N}$. These groups are expected to undergo changes in their intensity and position according to their environments [42].

Hydrogen bonding interactions are able to affect the frequency as well as the intensity and width of these vibrations. As these structures feature $\mathrm{N}-\mathrm{H} \cdots \mathrm{O}$ hydrogen bonds, the $\mathrm{N}-\mathrm{H}$ stretching modes are altered largely. In the high-frequency region, between 3600 and $2300 \mathrm{~cm}^{-1}$, the observed bands correspond to the stretching vibrations of the $\mathrm{N}-\mathrm{H}, \mathrm{C}-\mathrm{H}$ and $\mathrm{C}-\mathrm{N}$ groups [43]. The peaks appearing in the range $1461-1313 \mathrm{~cm}^{-1}$ can be assigned to $\mathrm{N}-\mathrm{H}$ bending modes of $\mathrm{NH}_{2}^{+}$and $\mathrm{NH}^{+}$. The bands in the 1642$1100 \mathrm{~cm}^{-1}$ region correspond to the aromatic $\mathrm{C}-\mathrm{C}$ and $\mathrm{C}-\mathrm{N}$ groups. The bands between 1000 and $700 \mathrm{~cm}^{-1}$ are assigned to the out-ofplane bending modes $\gamma\left(\mathrm{C}_{\text {ary }}-\mathrm{H}\right)$ and $\gamma\left(\mathrm{C}_{\text {ary }}-\mathrm{C}\right)$.

For the $\mathrm{NO}_{3}^{-}$anion, Figs. S13-a shows different groups of bands between 1400 and $700 \mathrm{~cm}^{-1}$. In this case, the intense peak appearing at $1313 \mathrm{~cm}^{-1}$ is attributed to the asymmetric stretching vibration of $\mathrm{NO}_{3}^{-}\left(\nu_{3}\right)$. The bands between 1140 and $940 \mathrm{~cm}^{-1}$ are related to the symmetric stretching modes $\nu\left(\mathrm{NO}_{3}\right)$. The shoulder at $823 \mathrm{~cm}^{-1}$ and the weak band at $721 \mathrm{~cm}^{-1}$ are attributed respectively to the $\gamma\left(\mathrm{NO}_{3}\right)$ in the plane bending and $\delta\left(\mathrm{NO}_{3}\right)$ out of the plane bending modes.
Fig. S14-b shows that the asymmetric stretching vibration of the $\mathrm{ClO}_{4}^{-}$anion is observed as intense peaks at 1067 and $1093 \mathrm{~cm}^{-1}$. The band at $713 \mathrm{~cm}^{-1}$ is assigned to a wagging vibration and the peak at $624 \mathrm{~cm}^{-1}$ is assigned to a twisting vibration of the anion.

DFT calculations of the frequencies were made on the geometry obtained after optimisation of the protons. An additional calculation was also made on the anion and the contributions of the two components were summed to lead the full spectrum. The resulting IR spectra between 500 and $4000 \mathrm{~cm}^{-1}$ are shown on Figs. S13-b for (I) and Figs. S14-b (II), respectively, and are very similar to the experimental ones. A close agreement between the experimental and theoretical wave numbers is mostly achieved in the
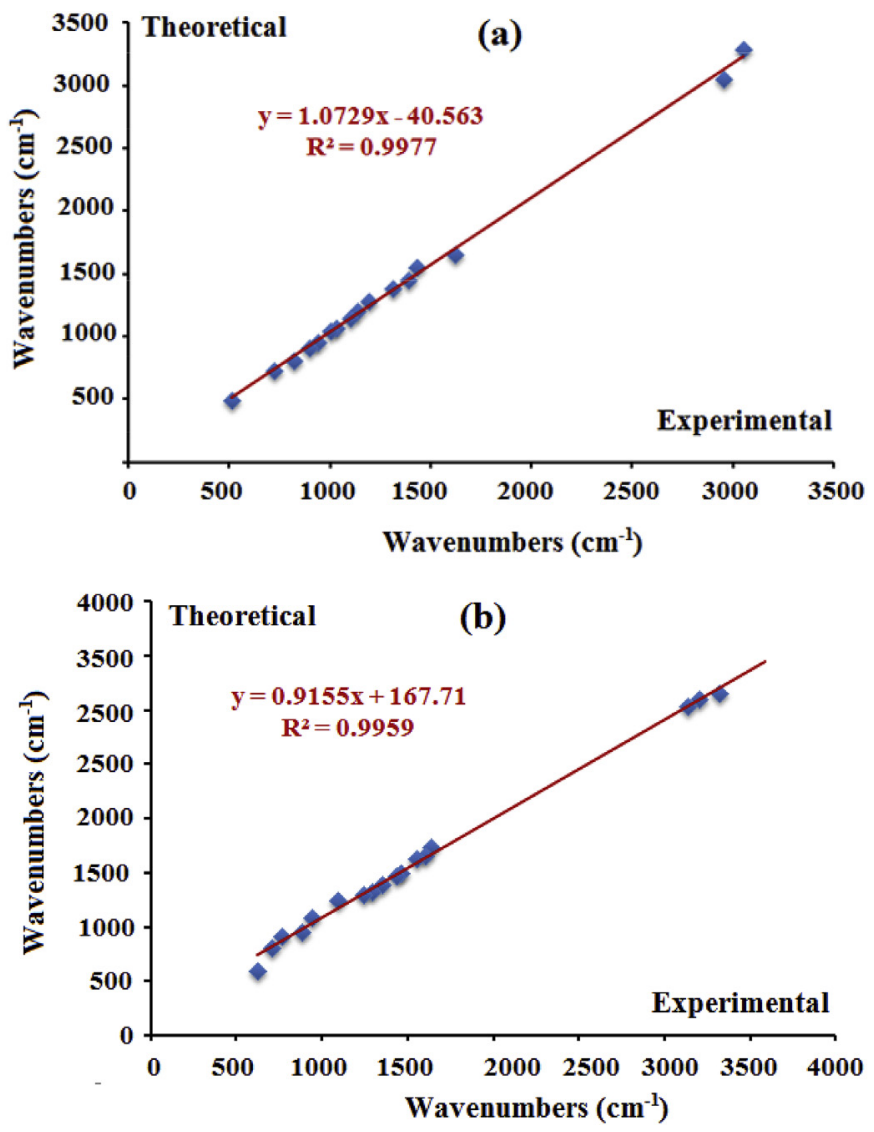

Fig. 9. Comparison between experimental and calculated IR frequencies. (a) (I) and (b) (II). 
finger print region as shown in Fig. 9-a for (I) and Fig. 9-b for (II). Thus, the precision is well-sufficient to assign the experimental frequencies and to confirm the attributions proposed above.

\section{Conclusion}

Both compounds, $\left(\mathrm{C}_{8} \mathrm{H}_{12} \mathrm{NO}\right)\left[\mathrm{NO}_{3}\right]$ (I) and $\left(\mathrm{C}_{8} \mathrm{H}_{14} \mathrm{~N}_{4}\right) \cdot\left[\mathrm{ClO}_{4}\right]_{2}$ (II), were characterized by single crystal X-ray diffraction, Hirshfeld surface analysis, DFT, Solid state NMR and FT-IR spectroscopy. According to our X-ray structural results, the different components are held together in the atomic arrangement by means of sets of hydrogen bonding contacts forming three-dimensional networks. Investigation of intermolecular interactions and crystal packing via Hirshfeld surface analysis reveals that the $\mathrm{O} \cdots \mathrm{H} / \mathrm{H} \cdots \mathrm{O}$ intermolecular interactions are the most abundant contacts of the organic cation in the crystal packing of both compounds. The enrichment ratio, derived from the Hirshfeld contact surface analysis, allows determining which types of contacts are over-or under-represented in crystal packing. The statistical analysis of crystal contacts reveals the driving forces in the packing formation. NMR signals are in full agreement with the crystallographic data. DFT calculations allow the attribution of the experimental NMR lines and of IR bands at low frequencies.

\section{Appendix A. Supplementary data}

Supplementary data related to this article can be found at https://doi.org/10.1016/j.molstruc.2018.02.032.

\section{References}

[1] L.-J. Baker, G.A. Bowmaker, P.C. Healy, B.W. Skelton, A.H. White, Crystal structure and spectroscopic studies of the complexes $\left[\mathrm{HgX}\left(\mathrm{NO}_{3}\right)\left(\mathrm{PPh}_{3}\right)\right](\mathrm{X}=$ Cl, Br or I), J. Chem. Soc. Dalton Trans. 6 (1992) 989-998.

[2] M.F. Perutz, L.F. TenEyck, Stereochemistry of cooperative effects in hemoglobin, in: Symp. Quant. Biol., 36, Cold Spring Harb, 1972, pp. 295-310.

[3] P. Czarnecki, W. Nawrocik, Z. Pajaxk, J. Nawrocik, Ferroelectric properties of pyridinium perchlorate, J. Phys. Condens. Matter 6 (1994) 4955-4960.

[4] O. Czupinski, G. Bator, Z. Ciunik, R. Jakubas, W. Medycki, J. SWiergiel, Structure, phase transitions and molecular motions in 4-aminopyridinium perchlorate, J. Phys. Condens. Matter 14 (2002) 8497-8512.

[5] O. Czupinski, M. Wojtas, J. Zaleski, R. Jakubas, W. Medycki, Structure and properties of 2-cyanopyridinium perchlorate [2-CNPyH][ClO 4$]$, J. Phys. Condens. Matter 18 (2006) 3307-3324.

[6] J.F. Vollano, R.O. Day, D.N. Rau, V. Chadrasekhar, R.R. Holmes, Pentacoordinated Molecules, Intramolecularly formed pentacoordinated structures oftriphenyltin esters of salicylic acid, o-anisic acid, and p-methylthiobenzoicacid, Inorg. Chem. 23 (1984) 3153-3160.

[7] K.C. Molloy, Solid state 119Sn NMR study of organotin carboxylates and thiophosphates, Inorg. Chem. Acta 141 (1988) 151-152.

[8] C. Peltinari, F. Marchetti, M. Pelli, A. Cingolani, L. Barba, A. Cassetta, Tin(IV) and organotin(IV) complexes containing mono or bidentate N-donor ligands II.14 Phenylimidazole derivatives. Crystal and molecular structure of [bis(4- phenylimidazole) trimethyltin(IV) ] chloride, J. Organomet. Chem. 515 (1996) $119-130$.

[9] S.K. Vasisht, T.P. Kaur, J. Kaushal, S. Dixit, Synthesis and characterization of sodium bis(trimethylstannyl) amide and bis(trimethylsilyl) bis(trimethylstannyl)-phospha- tetrazene, J. Organomet. Chem. 540 (1997) $51-54$.

[10] M. Gielen, Tin-based antitumour drugs, Coord. Chem. Rev. 151 (1996) 41-51.

[11] I. Bayar, L. Khedhiri, E. Jeanneau, F. Lefebvre, C. Ben Nasr, Crystal structure quantum mechanical study and spectroscopicstudies of nitrate and perchlorate salts of 3-chloroaniline, $\left[\mathrm{C}_{6} \mathrm{H}_{7} \mathrm{ClN}\right] \mathrm{NO}_{3}$ (I) and $\left[\mathrm{C}_{6} \mathrm{H}_{7} \mathrm{ClN}\right] \mathrm{ClO}_{4}$ (II), J. Mol. Struct. 1137 (2017) 373-379.

[12] K. Kaabi, M. El Glaoui, V. Ferretti, M. Zeller, C. Ben Nasr, 2-Amino-4-methyl-6oxo-3,6-dihydropyrimidin-1-ium perchlorate-2-amino-6-methylpyrimidin4(1H)-one-water (1/1/1), Acta Crystallogr. E67 (2011) o2507-o2508.

[13] G. Lommen, M. De Bruyn, M. Schroven, W. Verschueren, W. Janssens, J. Verrelst, J. Leysen, The discovery of a series of new non-indole $5 \mathrm{HT}_{1 \mathrm{D}}$ agonists.Bioorg, Med. Chem. Lett. 5 (1995) 2649-2654.

[14] D. Choi, J.P. Stables, H. Kohn, Synthesis and anticonvulsant activities of NBenzyl-2-acetamidopropionamide derivatives, J. Med. Chem. 39 (1996) 1907-1916.

[15] P. Morieux, J.P. Stables, H. Kohn, Synthesis and anticonvulsant activities of Nbenzyl-(2R)-2-acetamido-3-oxysubstituted propionamide derivatives, Bioorg.
Med. Chem. 16 (2008) 8968-8975.

[16] U. Peterson, Quinolone antibiotics: the development of moxifloxacin, in: J. Fischer, C.R. Ganellin (Eds.), Analogue-based Drug Discovery, John Wiley \& Sons, 2006, pp. 338-342. IUPAC.

[17] US patent 4654362, G.R.E. Van Lommen, M.F.L. De Bruyn \& M.F.J. Schroven, Derivatives of 2,2'-iminobisethanol, Janssen Pharmaceutica. (1987).

[18] G.H. Hitching, L.F. Kuyper, D.P. Baccananari, in: M. Sandler, H.J. Smith (Eds.), Design of Enzyme Inhibitors as Drugs, Oxford University Press, New York, 1988, p. 343.

[19] Z. Otwinowski, Z. Minor, C.W. Carter, R.M. Sweet (Eds.), Methods in Enzymology, Corrected for Lorentz-polarization and Absorption Effects, A 276, Academic Press London, 1977, pp. 307-326.

[20] R.H. Blessing, An empirical correction for absorption anisotropy, Acta Crystallogr. A 51 (1995) 33.

[21] A. Altomare, M.C. Burla, M. Camalli, G.L. Cascarano, C. Giacovazzo, A. Guagliardi, A. Grazia, G. Moliterni, G. Polidori, SIR97: a new tool for crystal structure determination and refinement, R. J. Spagna, App. Crystallogr. 32 (1999) 115-119.

[22] G.M. Sheldrick, SHELXL97, Program for Crystal Structure Refinement, University of Göttingen, Göttingen, Germany, 1997.

[23] L.J. Farrugia, Synthesis, Crystal Structure, Thermal, Decomposition of the new cadmium selenite chloride, Cd4(SeO3)2OCl2, J. Appl. Crystallogr. 32 (1999) 837.

[24] K. Brandenburg, Diamond Version 2.0 Impact GbR. Bonn, Germany, 1998.

[25] D. Cremer, J.A. Pople, General definition of ring puckering coordinates, J. Am. Chem. Soc. 97 (1975) 1354.

[26] J.J. McKinnon, M.A. Spackman, A.S. Mitchell, Novel tools for visualizing and exploring intermolecular interactions in molecular crystals, Acta Crystallogr. B 60 (2004) 627-668.

[27] F.L. Hirshfeld, Bonded-atom fragments for describing molecular charge densities, Theoretica. Chim. Acta 44 (1977) 129-138.

[28] M.A. Spackman, P.G. Byrom, A novel definition of a molecule in a crystal, Chem. Phys. Lett. 267 (1997) 215-220.

[29] M.A. Spackman, J.J. McKinnon, Fingerprinting intermolecular interactions in molecular crystals, CrystEngComm 4 (2002) 378-392.

[30] C. Jelsch, S. Soudani, C. Ben Nasr, Likelihood of atom-atom contacts in crystal structures of halogenated organic compounds, IUCrJ (2015) 2327-2340.

[31] C.F. Matta, J. Hernández-Trujillo, T.-H. Tang, R.F.W. Bader, Hydrogen-hydrogen bonding: a stabilizing interaction in molecules and crystals, Chem. Eur J. 9 (2003) 1940-1951.

[32] B. Guillot, E. Enrique, L. Huder, C. Jelsch, MoProViewer: a tool to study proteins from a charge density science perspective, Acta Crystallogr. A70 (2014). C279-C279.

[33] C. Jelsch, K. Ejsmont, L. Huder, The enrichment ratio of atomic contacts in crystals, an indicator derived from the Hirshfeld surface analysis, IUCrJ 1 (2014) 119-128.

[34] M.J. Frisch, G.W. Trucks, H.B. Schlegel, G.E. Scuseria, M.A. Robb, J.R. Cheeseman, G. Scalmani, V. Barone, B. Mennucci, G.A. Petersson, H. Nakatsuji, M. Caricato, X. Li, H.P. Hratchian, A.F. Izmaylov, J. Bloino, G. Zheng, J.L. Sonnenberg, M. Hada, M. Ehara, K. Toyota, R. Fukuda, J. Hasegawa, M. Ishida, T. Nakajima, Y. Honda, O. Kitao, H. Nakai, T. Vreven, J.A. Montgomery Jr., J.E. Peralta, F. Ogliaro, M. Bearpark, J.J. Heyd, E. Brothers, K.N. Kudin, V.N. Staroverov, T. Keith, R. Kobayashi, J. Normand, K. Raghavachari, A. Rendell, J.C. Burant, S.S. Iyengar, J. Tomasi, M. Cossi, N. Rega, J.M. Millam, M. Klene, J.E. Knox, J.B. Cross, V. Bakken, C. Adamo, J. Jaramillo, R. Gomperts, R.E. Stratmann, O. Yazyev, A.J. Austin, R. Cammi, C. Pomelli, J.W. Ochterski, R.L. Martin, K. Morokuma, V.G. Zakrzewski, G.A. Voth, P. Salvador, J.J. Dannenberg, S. Dapprich, A.D. Daniels, O. Farkas, J.B. Foresman, J.V. Ortiz, J. Cioslowski, D.J. Fox, Gaussian 09, Revision B.01Gaussian, Inc., Wallingford CT, 2010.

[35] R.G. Pearson, Absolute electronegativity and hardness correlated with molecular orbital theory, Proc. Natl. Acad. Sci. U. S. A 83 (22) (1986) 8440-8441.

[36] L. Xiao-Hong, L. Xiang-Ru, Z. Xian-Zhou, Molecular structure and vibrational spectra of three substituted 4-thioflavones by density functional theory and ab initio HartreeeFock calculations, Spectrochim. Acta. A 78 (2011) 528-536.

[37] D. Arul Dhas, I. Hubert Joe, S.D.D. Roy, T.H. Freeda, DFT computations and spectroscopic analysis of a pesticide: chlorothalonil, Spectrochim. Acta. A 177 (2010) 36-44.

[38] R.S. Mulliken, Electronic population analysis on LCAO-MO molecular wave functions, J. Chem. Phys. 23 (1955) 1833-1840.

[39] J. Skihsted, H.J. Jakobsen, $35 \mathrm{Cl}$ and $37 \mathrm{Cl}$ magic-angle spinning NMR spectroscopy in the characterization of inorganic perchlorates, Inorg. Chem. 38 (1999) 1806-1813.

[40] T.M. Klapötke, C. Miró Sabaté, The preparation and characterization of guanylurea nitrate and perchlorate salts, Heteroat. Chem. 19 (2008) 301-306.

[41] S. Gatfaoui, A. Mezni, T. Roisnel, H. Marouani, Synthesis, characterization, Hirshfeld surface analysis and antioxidant activity of a novel organic inorganic hybrid material 1-methylpiperazine-1,4-diium bis(nitrate), J. Mol. Struct. 1139 (2017) 52-59.

[42] S. Soudani, J.-X. Mi, F. Lefebvre, C. Jelsch, C. Ben Nasr, Synthesis and physicochemical studies of a novel layered structure with a heptanuclear Cd complex: $(\mathrm{C} 9 \mathrm{~N} 4 \mathrm{H} 28) \mathrm{Cd} 7(\mathrm{H} 2 \mathrm{O}) 2 \mathrm{Cl} 18 \cdot \mathrm{nH} 2 \mathrm{O}(\mathrm{n}=5.89)$, J. Mol. Struct. 1084 (2015) 46-54.

[43] W. Clegg, D.G. Watson, Anhydrous guanidinium 3,5-dinitrobenzoate, Acta Crystallogr. E63 (2007) 867-868. 